Jurnal Sastra Indonesia

REGISTER NELAYAN DI DESA BENDAR KECAMATAN JUWANA KABUPATEN PATI

\title{
Susanto $^{\bowtie}$, Hari Bakti Mardikantoro, Deby Luriawati
}

Jurusan Bahasa dan Sastra Indonesia, Fakultas Bahasa dan Seni, Universitas Negeri Semarang, Indonesia

Info Artikel

Sejarah Artikel:

Diterima April 2017

Disetujui Mei 2017

Dipublikasikan Maret

2018

\section{Keywords:}

Sociolinguistics, fishermen, the register of language, social identity, forms, meanings, functions of language, factor of language.

\section{Abstrak}

Penelitian ini bertujuan untuk mendeskripsikan bentuk, makna, fungsi dan pembentukan faktor-faktor penyebab daftar bahasa nelayan di Desa Bendar Kecamatan Juwana Pati. Penelitian ini dilakukan dengan menggunakan pendekatan deskriptif kualitatif dan sosiolinguistik. Data yang digunakan dalam penelitian ini dalam bentuk kata-kata dan frasa dari pidato adalah sekelompok nelayan. Pengumpulan data dilakukan melalui metode merujuk pada metode dan cakap. Data yang diperoleh kemudian dianalisis menggunakan metode agih dan tidak tentu. Metode tak tentu digunakan karena sebagian besar data dalam bentuk bahasa Jawa dan metode agih digunakan untuk mengetahui bentuk register bahasa nelayan mana. Hasil penelitian menunjukkan bahwa ada bentuk kata dan frasa pada register bahasa yang digunakan oleh sekelompok nelayan. Fungsi-fungsi yang terdapat dalam daftar bahasa nelayan yaitu: (1) fungsi referensial, (2) fungsi konatif, (3) fungsi emotif, (5) fungsi fatik, (6) fungsi puitik. Pembentukan daftar nelayan bahasa sebagai hasil dari faktor (1) pengaturan, (2) Peserta, (3) berakhir, (4) Urutan Undang-Undang, (5) instrumental, dan (6) norma.

\section{Abstract}

This study aims to describe the shape, the meaning, function and formation of the cause factors of language registers of fishermen in the Bendar village Subdistrict Juwana Pati. The research was conducted using a descriptive qualitative and sociolinguistic approaches. The data used in this research in the form of words and phrases from the speech is a group of fishermen. Data collection was done through methods refer to the method and ably. The data obtained are then analyzed using the method agih method and indeterminate. Indeterminate method is used because most of the data in the form of the Java language and the agih method is used to find out which form of language registers of fishermen. The results showed that there is a form of words and phrases on the register of the language used by a group of fishermen. The functions contained within the register of fishermen i.e. language: (1) referential function, (2) konatif function, (3) emotive function, (5) fatik function, (6) puitic function. The formation of the register of fishermen the language as a result of factors (1) settings, (2) Participant, (3) ends, (4) Act Sequence, (5) instrumental, and (6) norms.

(C) 2018 Universitas Negeri Semarang

$凶$ Alamat korespondensi:

ISSN 2252-6315

Gedung B1 Lantai 1 FBS Unnes

Kampus Sekaran, Gunungpati, Semarang, 50229

E-mail: santosasindo@gmail.com 


\section{PENDAHULUAN}

Bahasa sebagai alat komunikasi selalu memunculkan fenomena baru dalam ilmu kebahasaan. Fenomena kebahasaan tersebut terjadi sebagai akibat dari masyarakat pemakai bahasa yang beranekaragam.Kemampuan bahasa untuk hidup dan berkembang dapat memunculkan bahasa yang bervariasi. Hal tersebut sepaham dengan pendapat Mardikantoro (2012:204) yang menyatakan bahwa bahasa yang dimiliki oleh suatu masyarakat tutur dalam khazanah bahasanya selalu memiliki variasi. Hal itudisebabkan oleh kenyataan bahwa bahasa yang hidup dalam masyarakat selalu digunakan dalam peranperan sosial para penuturnya.

Setiap masyarakat pemakai bahasa selalu membawa bahasa dari kelompok sosialnya masing-masing. Hal ini dilakukan untuk menunjukkan identitas sosial kelompok tersebut. Salah satunya adalah kelompok nelayan. Nelayan muncul sebagai kelompok yang unik dan berbeda dengan kelompok lainnya. Mempertahankan tradisi dan kebudayaan sebagai penguat identitas kelompok mereka. Identitas yang terbentuk salah satunya melalui bahasa yang digunakan. Mardikanto dan Maula (2016:4393) mengatakan bahwa 'language is considered as one of ethic identities. Frequently the difference of mother tongue reflects ethnic difference. Ethnic dialect when speaking the same language also characterizes the differences'. Dalam hal ini bahasa dianggap sebagai salah satu identitas etika. Sering dengan perbedaan bahasa ibu yang mencerminkan perbedaan etnis. Dialek etnis ketika berbicara bahasa yang sama juga menjadi ciri pembeda.

Kelompok nelayan sudah dikenal dengan penggunaaan istilah-istilah atau kosakata yang khas dan mampu menjadikan identitas kelompok mereka.Pemakaian bahasa yang hanya diketahui dan digunakan oleh suatu kelompok masyarakat tertentu atas dasar kebutuhan dan kepentingannya dinamakan register.

Kelompok nelayan yang berada di Desa Bendar Kecamatan Juwana Kabupaten Pati tersebut tidak hanya berasal dari desa itu saja. Banyak pendatang baru yang berasal dari berbagai daerah dengan dialek yang berbeda. $\mathrm{Hal}$ ini turut memicu terbentuknya kosakata atau istilah-istilah yang baru dan khas dalam kelompok tersebut.Munculnya kelompok sosial yang beraneka ragam dan saling membawa bahasanya sendiri dapat menimbulkan permasalahan baru dalam proses komunikasi. Register hanya dapat dipahami oleh kelompok sosial tertentu saja. Kejadian tersebut akan menimbulkan saling ketidakmengertian dalam proses komunikasi antarkelompok sosial yang ada.

Penelitian ini menjadi menarik karena kelompok nelayan dianggap sebagai kelompok yang unik dibandingkan dengan kelompokkelompok sosial yang lain. Keunikan tersebut terlihat salah satunya melalui pola hidup dan tradisi masyarakat nelayan tersebut yang masih dijaga. Kehidupan masyarakat nelayan yang menghabiskan waktunya di laut yang bebas berpengaruh terhadap pola hidupnya. Penelitian ini memusatkan kajiannya terhadap bentuk, makna, fungsi, dan faktor penyebab terbentuknya register nelayan di Desa Bendar Kecamatan Juwana Kabupaten Pati.

\section{METODE}

Penelitian ini menggunakan pendekatan teoretis dan pendekatan metodologis. Pendekatan teoretis menggunakan pendekatan sosiolinguistik. Alasan menggunakan pendekatan sosiolinguistik karena penelitian ini mengkaji tentang penggunaan bahasa yang digunakan oleh sekelompok masyarakat tertentu yaitu kelompok nelayan. Pendekatan metodologis dalam penelitian ini menggunakan Pendekatan deskriptif kualitatif. Pendekatan deskriptif kualitatif menafsirkan dan menuturkan data yang bersangkutan 
dengan situasi yang sedang tejadi, sikap serta pandangan yang terjadi dalam suatu masyarakat, pertentangan dua keadaan atau lebih, hubungan antarvariabel, perbedaan antar fakta, pengaruh terhadapsuatu kondisi. Data yang digunakan dalam penelitian ini berupa kata dan frasa dari tuturan kelompok nelayan. Data diperoleh dengan menggunakan metode simak dengan teknik lanjutan yaitu teknik simaklibat cakap, teknik simak bebas libat cakap, teknik rekam dan teknik catat, dan metodecakap dengan teknik lanjutan teknik cakap semuka, teknik cakaptansemuka, teknik rekam dan teknik catat.

Analisis data dilakukan dengan menggunakan metode padan dan metode agih.Metode padan yang digunakan dalam penelitian ini yaitu metode padan translasional, karena objek penelitian menggunakan bahasa Jawa khas Kabupaten Pati. Oleh sebab itu harus dipadankan ke dalam bahasa Indonesia.Adapun teknik analisis data dalam metode padan yang digunakan peneliti untuk menjawab rumusan masalah yaitu dengan menggunakan teknik dasar pilah unsur penentu. Teknik dasar pilah unsur penentu (PUP) merupakan metode analisis dengan alat penentu yang berupa bahasa yang berbeda. Teknik PUP dilakukan dengan cara memilah kata atau frase yang diduga merupakan register nelayan di Desa Bendar tersebut

Metode agih digunakan dalam penelitian ini untuk menjelaskan unsur dari bahasa objek sasaran penelitian itu sendiri seperti bentuk kata, fungsi sintaksis, klausa, dll. Adapun teknik dasar dalam metode agih yang digunakan peneliti untuk menjawab bentuk dari register nelayan yang ditemukan menggunakan teknik bagi unsur langsung (BUL). Teknik ini digunakan untuk membagi satuan lingual datanya menjadi beberapa bagian atau unsur; dan unsur-unsur yang bersangkutan dipandang sebagai bagian yang langsung membentuk satuan lingual yang dimaksud.

\section{HASIL DAN PEMBAHASAN}

\section{Bentuk dan Makna Register Nelayan di Desa Bendar Kecamatan Juwana Kabupaten Pati.}

Bentuk register nelayan yang terdapat di Desa Bendar Kecamatan Juwana Kabupaten Pati diklasifikasikan menjadi dua yaitu bentuk kata dan bentuk frasa. Bentuk kata kemudian diklasifikasikan lagi menjadi bentuk kata monomorfemis (kata dasar) dan bentuk kata polimorfemis (kata kompleks).

\section{Klasifikasi Register Nelayan Desa Bendar Kecamatan Juwana Kabupaten Pati Bentuk Kata}

\section{Kata Dasar (Monomorfemis)}

Kata dasar (monomorfemis)adalah kata yangterdiri atas satu morfem yang dapat berdiri sendiri dan mempunyai makna tanpa adanya kehadiran bentuk lain. Register bentuk kata dasar (monomorfemis) pada kelompok nelayan di Desa Bendar Kecamatan Juwana Kabupaten Pati adalah sebagai berikut.

KONTEKS: SEORANG NELAYAN (N1) $\begin{array}{ll}\text { MENGELUH } & \text { KEPADA } \\ \text { JURU MUDI(N2) } & \text { KARENA } \\ \text { TIDAK } & \text { KUNJUNG } \\ \text { MENDAPATKAN IKAN. }\end{array}$

N1: "wis sol kaping pindho sawengi kok ora ngentukna iwak blas"

[wess ${ }^{\text {hol }}$ pey pinḍo səwəni kə? ora yənto?no iwa? blas]

'sudahsoldua kali dalam satu malam kok tidak mendapatkan ikan sama sekali'

N2: "Iha piye maneh, ya pancen ngeniku jenenge ora ana iwak"

[lha piye nCh yə ancEn yəniku jənəye ora ono iwa?]

'gimana lagi, memang seperti itu kalau sedang tidak ada ikan' 
(Data 13)

Dalam tuturan tersebut terdapat register yaitu 'sol' [s' ${ }^{\text {bl] }}$. Register 'sol' [s' ${ }^{\text {bl] }}$ digunakan oleh kelompok nelayan untuk menyebutkan Perpindahan lokasi penangkapan ikan. Bentuk dari register 'sol' [s'bl]adalah kata dasar. Dapat dikatakan kata dasar karena register 'sol' [s $\mathbf{s}^{\text {h}} \mathbf{l}$ ] tidak mengalami proses morfologis. Selain itu register'sol' [s ${ }^{\mathbf{h}}$ l]termasuk dalam kelas kata verba karena menunjukkan suatu bentuk aktivitas/ kegiatan yaitu melakukan perpindahan penangkapan ikan dari suatu titik penangkapan menuju titik penangkapan yang lain.

Contoh lain yang termasuk dalam register nelayan bentuk kata dasar (monomorfemis) adalah sebagai berikut.

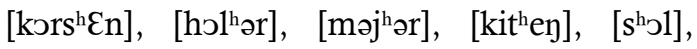

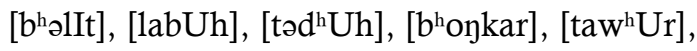
[b $\left.{ }^{\text {hagh }}{ }^{\text {Cn }}\right]$, [lelay], [alon], [la?Ib], [1Ub $\left.{ }^{\text {hay }}\right]$,

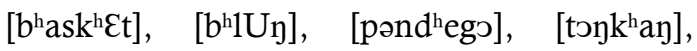

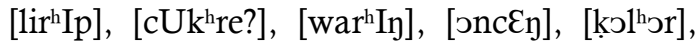

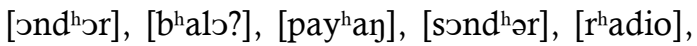
[linghi], [ghola?], dan [tunas].

\section{Kata Kompleks (Polimorfemis)}

Kata kompleks (polimorfemis) adalah kata yang terdiri atas lebih dari satu morfem, kata monomorfemis terbentuk melalui proses morfologis. Ciri-ciri penggunaan register dengan bentuk kata kompleks (polimorfemis) tersebut biasanyasalah satunya ditandai dengan adanya afiksasi. Afiksasi tersebut antara lain prefiks, sufiks, infiks, dll. Berikut akan dipaparkan register nelayan di Desa Bendar Kecamatan Juwana Kabupaten Pati yang menggunakan bentuk kata kompleks (polimorfemis).

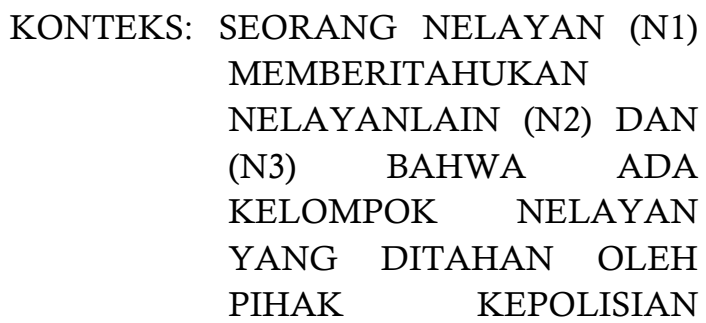

KARENA MELAKUKAN PENANGKAPAN IKAN SECARA TIDAK BENAR.

N1 : "abane dhek wingi kapale Sobirin dicekel polisi kang, dhak wis pada weruh kuwe?"

[abane nḍe? wingi kapal e sobirin dicəkəl polisi kay nḍa? wes do roh kuwe]

'kabarnya kemarin kapalnya Sobirin di tangkap polisi kak, apa kamu sudah tahu?'

N2 : "Tha piye, wong kapale dhe Sobirin malah nyantrang"

[lha piye woy kapale dhe Sobirin malah ñanthray]

'gimana lagi, kan kapalnya paman Sobirin nyantrang'

N1 : "wis weruh nyantrang iki ora oleh kok isih mangkat wae"

[wes roh nek ñanthrayiku ora JlEh kok ijEh mangkat wae]

'sudah tahu nyantrang itu tidak boleh kok masih berangkat saja

N3 : "jenenge wae wong luru duwit kangkang"

[jenene ae woy luru duI? Kangkang]

'namanya saja cari uang kak-kak'

\section{(Data 2)}

Dalam konteks tuturan nelayan tersebut ditemukan register'nyantrang' [ñanthrap]. Register 'nyantrang' [ñant ${ }^{\mathrm{h}}$ raj]mempunyai makna kegiatan dari suatu kelompok nelayan yang cara penangkapan ikannya dengan memasang jaring sampai ke dasar laut sehingga tanah dan terumbu karang mampu terjaring. Register tersebut berbentuk kata kompleks karena sudah mengalami proses morfologis yaitu (ny+cantrang) dan termasuk dalam kelas kata verba karena menunjukkan suatu bentuk kegiatan/ aktivitas (kata kerja). 
Contoh lain yang termasuk dalam register nelayan bentuk kata kompleks (polimorfemis) adalah sebagai berikut.

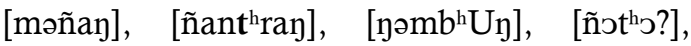

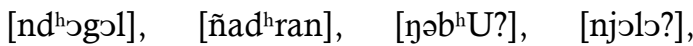

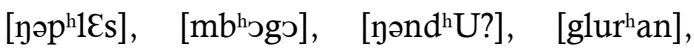
[yomp ${ }^{\text {hall] }}$ [tari?an], [yวb ${ }^{\text {hor }}$ ], [yisi], [yasa?i], [ñamb ${ }^{\mathrm{h}}$ uri], [mingIr], [kəch ${ }^{\mathrm{h}}$ lan], [montor $\left.{ }^{\mathrm{h}} \mathrm{Is}\right]$, [tamb ${ }^{\text {hanan }}$ ], [pənamp ${ }^{\mathrm{h} U y]}$ [kolonan],

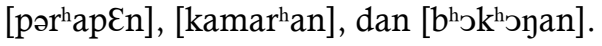

\section{Klasifikasi Register Nelayan Desa Bendar Kecamatan Juwana Kabupaten Pati Bentuk Frasa}

Penggunaan register bentuk frasa bagi kelompok nelayan dapat ditandai dengan adanya gabungan dua kata atau lebih. Berikut akan dipaparkan register bentuk frasa yang digunkan oleh kelompok nelayan di Desa Bendr Kecamatan Juwana Kabupaten Pati.

\section{KONTEKS: SEORANG JURU MUDI (N1) MEMERINTAHKAN \\ ANAKBUAHNYA \\ UNTUK BERSIAP-SIAP MELAKUKAN SEBUAH PEKERJAANNYA.}

N1: "Jangkare wis tak mudhunke lho, ndang siap-siap ngompal Lik!"

[jaykar e wIs ta? ḍUnke lho nḍay siapsiap yompal le?]

'jangkarnya sudah diturunkan, segera siap-siap [nJmpal]om'

N2: "ya sik kang, Jumardi wis pada nyemplung kok"

[yว se? kay jumari wIs ḍ̣ ñəmplUy ko?]

'iya sebentar kak, Jumari sudah menceburkan diri kok'

N1: "juru lampu karo juru aruse ben ngobor sik kang"

$\left[\mathbf{j}^{\mathrm{h}} \mathbf{u} \mathbf{r}^{\mathrm{h}} \mathbf{u}\right.$ lamp $^{\mathrm{h}} \mathbf{u}$ karo juru arUs $b E n$ yobor se? kay] 'juru lampu sama juru arusbiar ngobordulu kak'

(Data 35)

Register yang ditemukan dalam tuturan nelayan tersebut adalah 'juru lampu' $\left[\mathbf{j}^{\mathrm{h}} \mathbf{u} \mathbf{r}^{\mathrm{h}} \mathbf{u}\right.$ lamp $p^{\text {hu}}$. Dilihat dari bentuknya register tersebut terdiri atas dua suku kata yaitu 'juru' dan 'lampu' sehingga menunjukkan bahwa register tersebut merupakan frasa. Dalam arti sebenarnya 'juru' bermakna orang yang ahli dalam bidang tertentu. 'lampu' bermakna sejenis benda yang berfungsi sebagai penerangan. Jadi dalam makna secara umum 'juru lampu' 'j $^{\mathrm{h}} \mathbf{u} \mathbf{r}^{\mathrm{h}} \mathbf{u}$ lamp $\left.\mathbf{p}^{\mathrm{h}} \mathbf{u}\right]$ berarti orang yang ahli dalam bidang lampu. Akan tetapi kelompok nelayan memaknai lampu sebagai seseorang yang mempunyai jabatan/ tugas memancarkan lampu untuk menarik perhatian ikan sehingga mendekati jaring yang sudah di sebar. Register 'juru lampu' [ [j ${ }^{\mathrm{h}} \mathbf{u} \mathbf{r}^{\mathrm{h}} \mathbf{u}$ lamp $\mathbf{p}^{\mathrm{h}} \mathbf{u}$ ]termasuk dalam kelas kata verba (kata kerja) karena menunjukkan suatu bentuk kegiatan/ aktivitas.

Contoh lain yang termasuk dalam register nelayan bentuk frasa adalah sebagai berikut.

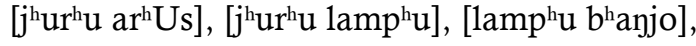
dan [lamp ${ }^{\text {h }} \mathbf{u} \mathbf{s}^{\text {hamion}}$ ].

\section{Fungsi Register Nelayan di Desa Bendar Kecamatan Juwana Kabupaten Pati.}

Register yang digunakan oleh kelompok nelayan di Desa Bendar Kecamatan Juwana Kabupaten Pati memiliki beberapa fungsi. Fungsi tersebut antara lain fungsi referensial, fungsi konatif, fungsi emotif, fungsi fatik, dan fungsi puitik.

\section{Fungsi Referensial}

Fungsi referensial yang terdapat dalam register nelayan di Desa Bendar Kecamatan Juwana Kabupaten Pati dapat dilihat ketika kelompok nelayan sedang membicarakan topik tertentu. Dalam hal ini 
bahasa berfungsi sebagai alat untuk membicarakan objek atau peristiwa yang ada disekeliling kelompok nelayan dapat pula berupa tradisi/ budaya kelompok nelayan. Register nelayan yang termasuk dalam fungsi referensial adalah 'nyantrang' [ñant $\left.{ }^{\mathrm{h}} \mathrm{raj}\right]$.

Termasuk dalam fungsi referensial karena register 'nyantrang' [ñant ${ }^{\text {hran] digunakan }}$ sebagai alat untuk membicarakan peristiwa yang ada di sekeliling penutur dengan budaya yang ada. Budaya yang dimaksud dalam konteks ini adalah kegiatan 'nyantrang' [ñanthray]. Makna 'nyantrang' [ñanthray] yang berartisuatu kelompok nelayan yang cara penangkapan ikannya dengan memasang jaring sampai ke dasar laut sehingga tanah dan terumbu karang mampu terjaring. Berdasarkan pengertian tersebut banyaknya nelayan yang ada kemudian mengelompokkan diri menjadi beberapa kelompok nelayan. Pengelompokkan ini dilakukan berdasarkan cara/ jenis ikan apa yang akan dicari. Maka dari itu 'nyantrang'

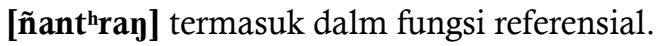

Contoh lain yang termasuk dalam register nelayan fungsi referensial adalah sebagai berikut.

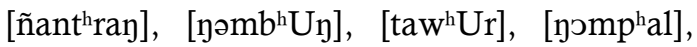

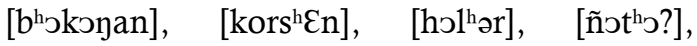

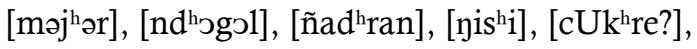

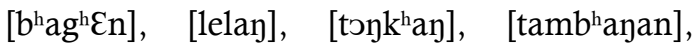

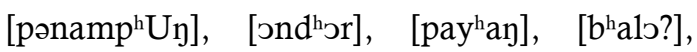

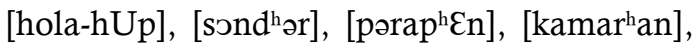
[linghi], [ghola?], dan [tunas].

\section{Fungsi Konatif}

Fungsi konatif yang terdapat dalam register nelayan di Desa Bendar Kecamatan Juwana Kabupaten Pati mengacu pada sebuah perintah, imbauan, atau permintaan penutur. Dalam hal ini mitra tutur/ lawan tutur menjadi tumpuan. Fungsi konatif digunakan agar lawan tutur berbuat sesuatu sesuai yang diinginkan penutur. Register nelayan yang termasuk dalam fungsi konatif adalah 'kiteng' [kit ${ }^{\mathrm{h}}$ ]].

Termasuk dalam fungsi konatif karena konteks dalam tuturan tersebut menyatakan seorang nelayan yang memerintahkan nelayan lain untuk melakukan pekerjaan 'kiteng' [kithen]. Berdasarkan makna yang terkandung dalam register 'kiteng' [kithen]tersebut yaitu suatu kegiatan memperbaiki jaring yang telah rusak setelah melaut. Register'kiteng' [kithen]disini berfungsi sebagai perintah/ permintaan untuk membuat pendengar melakukan sesuatu.

Contoh lain yang termasuk dalam register nelayan fungsi konatif adalah sebagai berikut.

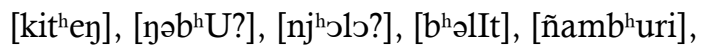
[yasa?i], [mb ${ }^{\mathrm{h}}$ go $], \quad\left[\mathrm{y}^{\mathrm{h}} 1 \mathrm{ks}\right], \quad\left[\mathrm{b}^{\mathrm{h}}\right.$ onk $\left.\mathrm{k}^{\mathrm{h}} \mathrm{ar}\right]$,

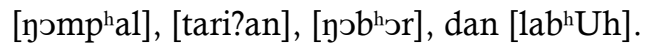

\section{Fungsi Emotif}

Fungsi emotif yang terdapat dalam register nelayan digunakan sebagai pengungkap rasa gembira, rasa sedih, rasa marah, dan lain sebagainya. Dalam hal ini adanya beberapa perasaan yang tampak dalam kelompok nelayan tertuang dalam sebuah istilah khas yaitu register. Register nelayan yang termasuk dalam fungsi emotif adalah 'along' [alon].

Fungsi emotif dalam register' along' [alon] tersebut memperlihatkan suatu perasaan senang. Hal tersebut dapat diketahui karena register 'along' [aloy] yang memiliki makna mendapatkan pembagian (bayaran/ gaji) dari hasil melaut yang banyak/ melimpah. Kejadian 'along' [aloy] semacam itu menjadi kebahagiaan tersendiri bagi kelompok nelayan. Berdasarkan perasaan bahagia tersebut kemudian muncul istilah 'along' [aloy] yang muncul berdasasarkan 
kesepakatan antar kelompok nelayan sehingga menjadi terbiasa.

Contoh lain yang termasuk dalam register nelayan fungsi emotif adalah sebagai berikut.

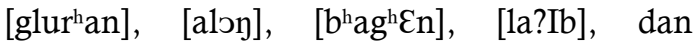
[təd $\left.{ }^{\mathrm{h}} \mathrm{Uh}\right]$

\section{Fungsi Fatik}

Fungsi fatik yang terkandung dalam register nelayan mengarah pada suatu bentuk kontak sosial. Artinya register yang digunkan bertujuan untuk menjalin hubungan, memelihar dan memperlihatkan perasaan bersahabat atau dlm rti lain untuk menunjukkan solidaritas sosial antar kelompok nelayan. Register nelayan yang termasuk dalam fungsi fatik adalah 'kecilan' [kəc ${ }^{\text {hilan] }}$.

Fungsi fatik dalam register tersebut ditunjukkan oleh kelompok nelayan untuk melakukan kontak langsung dengan nelayan lain. Dalam arti menjalin hubungan sosial. Adanya bentuk solidaritas sosial antarkelompok nelayan melalui register 'kecilan' [kəchilan] yang mempunyai makna tugas/ jabatan dari seorang nelayan yang hanya ditugaskan memasak untuk anak buah kapal selama melaut. Adanya suatu bentuk jsa yang dilakukan oleh nelayan yang ditugaskan untuk memasak untuk nelayan lain diberikan istilah 'kecilan' [kəchilan] tersebut.

Contoh lain yang termasuk dalam register nelayan fungsi fatik adalah sebagai berikut.

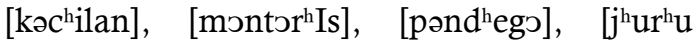
$\left.\operatorname{ar}^{h} U s\right]$, dan [jh ${ }^{h}{ }^{h} u$ lamp $\left.p^{h} u\right]$.

\section{Fungsi Puitik}

Fungsi puitik dalam register nelayan di Desa Bendar Kecamatan Juwana Kabupaten
Pati digunakan untuk menyampaikan suatu nilai estetis (keindahan) dalam sebuah bahasa khas yang digunakan. Selain itu fungsi puitik juga digunakan untuk menyampaikan amanat atau pesan tertentu yng masih mengarah pada nilai estetiknya. Register nelayan yang termasuk dalam fungsi puitik adalah 'lampu bangjo' [lamp ${ }^{\text {h }} \mathbf{u} \mathbf{b}^{\text {hanj }}{ }^{\text {ho }}$.

Fungsi register 'lampu bangjo' [lamp ${ }^{\mathrm{h}} \mathbf{u}$ $\mathbf{b}^{\text {hanj }}{ }^{\text {hol }}$ ] sebagai lambang untuk memberika efek estetis bagi objek yang dimaksudkan yaitu 'lampu bangjo' [lamp ${ }^{\text {h}} \mathbf{u}$ b $^{\text {hanj }}{ }^{\text {ho }}$ ].Kata 'bangjo' dalam register tersebut merupakan bentuk singkatan dari kata 'abang' dan 'ijo'. Adanya singkatan yang digunakan oleh kelompok nelayan tersebut menimbulkan efek estetis dalam frasa pada register 'lampu bangjo' [lamp $p^{\text {h }} \mathbf{u} \mathbf{b}^{\text {hanj }}{ }^{\text {ho }}$ ].

Contoh lain yang termasuk dalam register nelayan fungsipuitik adalah sebagai berikut:

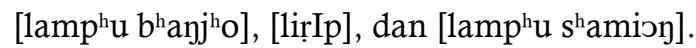

\section{Faktor Terbentuknya Register Nelayan di Desa Bendar Kecamatan Juwana Kabupaten Pati.}

Terbentuknya register yang digunakan oleh kelompok nelayan di Desa Bendar Kecamatan Juwana Kabupaten Pati dipengaruhi oleh beberapa faktor. Faktor tersebut yaitu faktor setting (latar), faktor participant (peserta), faktorends (tujuan), faktor act sequence (topik tuturan), Faktor instrumentalis (sarana), faktor norms (norma). Temuan faktor tersebut menunjukkan adanya suatu tradisi/ budaya kelompok nelayan dalam melakukan kegiatannya. Sebagian register yang ada terbentuk berdasarkan kegiatan yang dilakukan oleh kelompok nelayan.

\section{Faktor Setting (latar)}


Faktor setting (latar) dalam register yang digunakan oleh kelompok nelayan di Desa Bendar Kecamatan Juwana Kabupaten Pati ditunjukkan melalui bagaimana tempat dan suasana tutur mampu mempengaruhi terbentuknya register. Faktor setting (latar) ini juga didasarkan atas tradisi dari sebuah kegiatan yang dilakukan oleh kelompok nelayan secara turun temurun. Register nelayan yang termasuk dalam faktor Setting (latar) adalah 'menyang' [məñan].

Terbentuknya register 'menyang' [məñan] tersebut karena adanya kesepakatan menggunakan bahasa pada masing-masing nelayan. Penggunaan bahasa tersebut mengacu pada kondisi lingkungan masyarakat nelayan tersebut secara turun temurun. Sehingga dapat diketahui bahwa terbentuknya register tersebut sebagai akibat dari faktor setting (latar). Kata 'menyang' dalam bahasa Jawa pada umumnya mempunyai makna berangkat. Akan tetapi kelompok nelayan menggunaknnya untuk menyebutkan sebagai suatu kegiatn melaut. Hal tersebut yang menguatkan adanya faktor setting (latar) dalam terbentuknya register tersebut.

Contoh lain yang termasuk dalam register nelayan faktor setting (latar) adalah sebagai berikut.

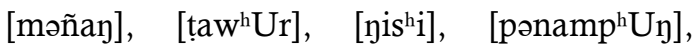

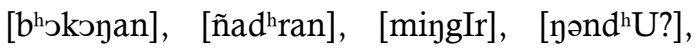

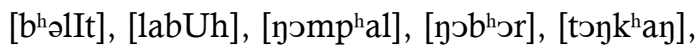

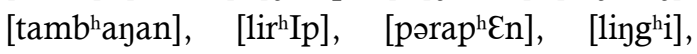
[ghola?], dan [tunas].

\section{Faktor Participant (Peserta)}

Adanya faktor participant (peserta) yang mengacu pada pemilihan bahasa yang ditentukan oleh perbedaan dimensi vertikal dan dimensi horizontal. Dimensi vertical mengacu pada perbedaan umur, status sosial/ ekanami, dan kedudukan dalam masyarakat. Sedangkan dimensi horizontal mengrah pada perbedaan tingkat keakraban antarpeserta tutur. Register nelayan yang termasuk dalam faktorparticipant (peserta) adalah 'nyantrang' [ñant ${ }^{\text {hran] }}$.

Faktor yang mempengaruhi terbentuknya register 'nyantrang' [ñant ${ }^{\text {hray] }}$ adalah participant (peserta tutur). 'nyantrang'

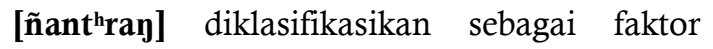
participant (peserta tutur) karena mengacu pada penutur dan mitra tutur. Maksud dari acuannya dari penutur dan mitra tutur karena adanya penggolongan kelompok nelayan yang dalam konteks ini 'nyantrang' [ñanthray]dimaknai sebagai suatu kelompok nelayanyang cara penangkapan ikannya dengan memasang jaring sampai ke dasar laut. Penggolongan tersebut dilakukan berdasarkan kesamaan status sosial walaupun sama-sama dari kelompok nelayan tetapi memiliki cara yang berbeda dalam proses melaut.

Contoh lain yang termasuk dalam register nelayan faktor participant (peserta) adalah sebagai berikut.

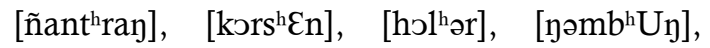

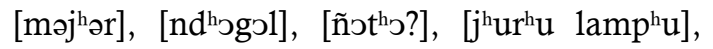
dan [jhurh ar $\left.^{\mathrm{h}} \mathrm{Us}\right]$.

\section{Faktor Ends (Tujuan)}

Faktor ends (tujuan) mengarah terhadap tujuan yang ingin disampaikan oleh penutur. Dalam hal ini mitra tutur yang menjadi sasarannya. Artinya adalah suatu tuturan bertujuan untuk menyampaikan buah pikiran, membujuk, dan mengubah perilaku (konatif). Register nelayan yang termasuk dalam faktorends (tujuan tutur) adalah 'njolok' [njh ${ }^{\mathrm{h}} \mathrm{l} \mathbf{l}$ ??].

Faktor yang mempengaruhi terbentuknya register 'njolok' [nj'blı?] adalah faktor ends (tujuan). Dalam konteks tuturan nelayan tersebut register 'njolok' [nj' $\mathbf{b l}$ J?] tampak memberikan suatu penjelasan tentang sebuah perintah dari pekerjaan nelayan tersebut yaitu mengulur tali kapal yang akan berangkat 
melaut. Perintah atau permintaan tersebut ditujukan kepada lawan tutur sebagai sasarannya. Yang mana dalam register 'njolok' [nj'blo?] tersebut bermaksud menyampaikan sebuah pikiran kepada lawan tuturnya.

Contoh lain yang termasuk dalam register nelayan faktor ends (tujuan) adalah sebagai berikut.

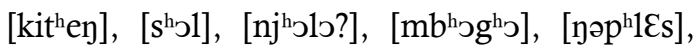

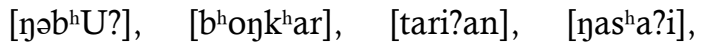
[ñamb $\left.{ }^{\mathrm{h} u r i}\right]$

\section{Faktor Act Sequence (Topik)}

Register nelayan di Desa Bendar Kecamatan Juwana Kabupaten Pati yang terbentuk atas faktor act sequence (topik) mengacu pada apa yang dibicarakan. Dalam sebuah peristiwa tutur, beberapa topik tutur dapat muncul secara berurutan. Perubahan topik tutur tersebut akan berdampak terhadap pemilihan bahasa yang digunakan. Register nelayan yang termasuk dalam faktor act sequence (topik) adalah gluran' [glur ${ }^{\mathrm{h} a n]}$.

Faktor terbentuknya register tersebut adalah act sequence (topik). Faktor act sequence (topik) mengacu pada topik tuturan yang dilakukan oleh nelayan tersebut ketika berada pada suatu kondisi cuaca yang kurang baik untuk melaut. Maka dari itu untuk memudahkannya dalam mendeskripsikan topik pembicaraan tersebut digunakan istilah khas gluran' [glurhan].

Contoh lain yang termasuk dalam register nelayan faktor act sequence (topik tuturan) adalah sebagai berikut.

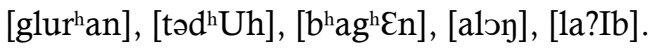

\section{Faktor Instrumentalis (Sarana)}

Fakto rinstrumentalis (sarana) yang memengaruhi terbentuknya register nelayan di Desa Bendar Kecamatan Juwana Kabupaten Pati mengacu terhadap variasi bahasa yang digunakan untuk mengungkapkan sesuatu. Dalam konteks ini yang dimaksudkan adalah sarana tutur (benda/alat) yang dilambangkan dengan suatu istilah tertentu. Register nelayan yang termasuk dalam faktor instrumentalis (sarana) adalah 'basket' [ $\left.\mathbf{b}^{\mathbf{h}} \mathbf{a s k}^{\mathbf{h}} \mathbf{E t}\right]$.

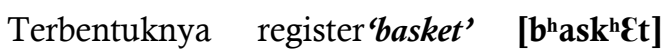
karena adanya faktor instrumentalis (sarana tutur). Dalam konteks tuturan nelayan tersebut istilah 'basket' [ [b $\left.{ }^{\text {hask }} \mathbf{k}^{\mathbf{h}} \mathbf{E t}\right]$ digunakan sebagai sarana dalam mengungkapkan suatu maksud kepada lawan tuturnya. Berdasarkan arti dalam bahasa Indonesia 'basket' [ $\mathbf{b}^{\mathbf{h}} \mathbf{a s k}^{\mathrm{h}} \mathbf{E t}$ ] berarti sejenis permainan olahraga dengan cara permainan memanyulkan bola, akan tetapi kelompok nelayan menggunakan istilah 'basket' [ $\left.\left.\mathbf{b}^{\mathbf{h}} \mathbf{a s k} \mathbf{k}^{\mathbf{h}} \mathbf{E}\right] \mathbf{t}\right]$ tersebut untuk memaknai sejenis tempat penyimpanan ikan. Berdasarkan hal tersebut tampak adanya fungsi instrumentalis yang

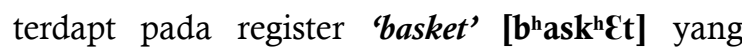
mengacu sebagai sarana tutur.

Contoh lain yang termasuk dalam register nelayan faktor instrumentalis (sarana) adalah sebagai berikut.

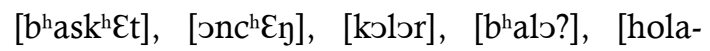

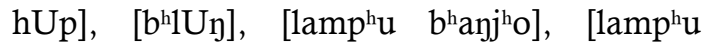

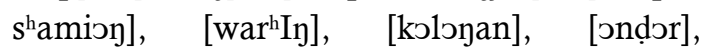

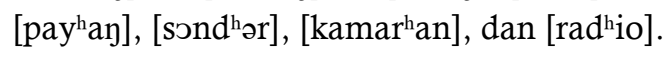

\section{Faktor Norms (Norma)}

Terbentuknya register nelayan di Desa Bendar Kecamatan Juwana Kabupaten Pati yang dipengaruhi oleh faktor norms (norma) merujuk pada boleh tidhaknya sesuatu digunakan oleh peserta tutur pada suatu konteks tertentu. Maksudnya adalah dalam hal kesantunan bahasa yang digunakan. Melihat dengan siapa tuturan berlangsung, dalam situasi seperti apa, dan dengan konteks yang seperti apa. Register nelayan yang termasuk dalam faktor norms (norma) adalah 'kecilan' [kəchilan].

Terbentuknya register 'kecilan' [kəch'ilan] dalam tuturan nelayan tersebut dipengaruhi oleh faktor norms (norma). Adanya unsur penghormatan yang dilakukan antarkelompok 
nelayan melalui istilah 'kecilan' [kəchilan] untuk menyebutkan sebuah tugas/ jabatan bagi salah seorang nelayan yang ditugaskan memasak untuk nelayan yang ada selama kegiatan melaut. Hal tersebut termasuk dalam norma interprestasi yang hanya dimiliki oleh seorang nelayan tertentu.

Contoh lain yang termasuk dalam register nelayan faktor norms (norma) adalah sebagai berikut.

[kəchilan], [montər $\left.{ }^{\mathrm{h}} \mathrm{Is}\right]$, dan [pənd ${ }^{\mathrm{h}} \mathrm{eg}$ ].

\section{SIMPULAN DAN SARAN}

Berdasarkan analisis data tersebut, dapat disimpulkan tiga hal berikut. Pertama, bentuk register yang digunakan oleh kelompok nelayan di Desa Bendar Kecamatan Juwana Kabupaten Pati diklasifikasikan menjadi dua yaitu bentuk kata dan bentuk frasa. Bentuk kata kemudian diklasifikasikan lagi menjadi bentuk kata monomorfemis (kata dasar) dan bentuk kata polimorfemis (kata kompleks). Kedua, ditemukan fungsi register yaitu: (1) fungsi referensial, (2) fungsi konatif, (3) fungsi emotif, (4) fungsi fatik, dan (5) fungsi puitik. Terbentuknya register nelayan tersebut sebagai akibat dari faktor (1) setting (latar), (2) Participant (peserta), (3) ends (tujuan), (4) Act Sequence (topik), (5) instrumentalis (sarana), dan (6) norms (norma).

Saran yang berkaitan dengan perkembangan penelitian berikutnya. Pertama, perlu adanya upaya pemertahanan dalam menggunakan istilah-istilah/ kosa kata khusus untuk memperkuat identitas kelompok nelayan tersebut melalui bahasa. Hal ini dilakukan agar tradisi atau kebudayaan yang terdapat pada kelompok nelayan di Desa Bendar Kecamatan Juwana Kabupaten Pati tidak punah. Kedua, banyak kajian kebahasan lain yang menarik untuk diungkap dari kelompok nelayan di Desa Bendar Kecamatan Juwana Kabupaten Pati selain register. Pengkajian lebih mendalam bisa dengan meneliti pergeseran bahasa nelayan, pemertahanan bahasa nelayan, maupun alih kode dan campur kode. Mengingat Desa Bendar yang banyak dikunjungi oleh pendatang-pendatang baru dari daerah yang berbeda.

\section{DAFTAR PUSTAKA}

Alwasilah, A. Chaedar. 1993. Pengantar Sosiologi Bahasa. Bandung: Angkasa Bandung.

Chaer, Abdul dan Agustina, Leonie. 1995. Sosiolinguistik: Perkenalan Awal. Jakarta: Rineka Cipta.

Chaer, Abdul. 2007. Linguistik Umum. Jakarta: Rineka Cipta.

Mardikantoro, Hari Bakti. 2013. "Bahasa Jawa sebagai Pengungkap Kearifan Lokal Masyarakat Samin di Kabupaten Blora". Jurnal Komunitas. Vol. 5 (2) Hlm. 197-207.

Mardikantoro, Hari Bakti dan Marreta, Yoris Adi. 2016. "Language Shift of Javanese and its Impacts on the Transformation of Samin Community". Man in India. Vol. 96. Hlm. 43934406.

Nababan, P.W.J. 1993. Sosiolinguistik Suatu Pengantar. Jakarta: PT GramediaPustaka Utama.

Rokhman, Fathur. 2013. Sosiolinguistik: Suatu Pendekatan Pembelajaran Bahasa dalam Masyarakat Multikultural. Yogyakarta: Graha Ilmu.

Samsuri. 1987. Analisis Bahasa (Memahami Bahasa Secara Ilmiah). Jakarta: Erlangga. 
Soeparno. 2003. Dasar-Dasar Linguistik. Yogyakarta: Mitra Gama Widya.

Sudaryanto. 2015. Metode dan Aneka Teknik Analisis Bahasa. Yogyakarta: Sanata Dharma University Press.

Verhaar, J. M. W. 2004. Asas-Asas Linguistik Umum. Yogyakarta: University Press.

Wahab, Abdul. 1995. Teori Semantik. Surabaya: Airlangga University Press.

Wijana, Dewa Putu dan Rohmadi, Muhammad. 2013. Sosiolinguistik: Kajian Teoretis dan Analisis. Surakarta: Pustaka Pelajar Offset. 